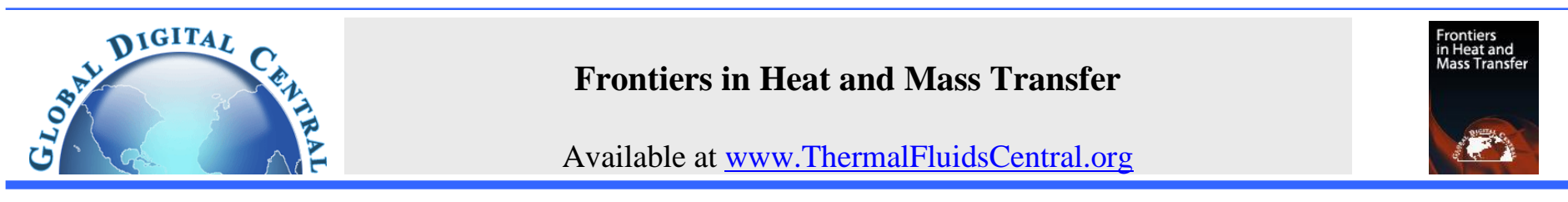

\title{
CONVECTIVE HOT AIR DRYING KINETICS OF RED BEETROOT IN THIN LAYERS
}

\author{
Abhishek Dasore ${ }^{a^{*}}$, Tarun Polavarapu ${ }^{\mathrm{b}}$, Ramakrishna Konijeti ${ }^{\mathrm{c}}$, Naveen Puppala ${ }^{\mathrm{d}}$, \\ ${ }^{a}$ Assistant Professor, School of Mechanical Engineering, RGM College of Engineering and Technology, Nandyal, Andhra Pradesh, 518501, India \\ ${ }^{b}$ Assistant Professor, Department of Mechanical Engineering, SRK Institute of Technology, Vijayawada, Andhra Pradesh, 521108, India \\ ${ }^{c}$ Professor, Department of Mechanical Engineering, Koneru Lakshmaiah Education Foundation, Guntur, Andhra Pradesh, 522502, India \\ d Professor, Agricultural Science Centre at Clovis, College of Agricultural, Consumer and Environmental Sciences, NMSU, NM, 88101, USA
}

\begin{abstract}
The effect of air temperature on drying kinetics of red beetroot slices was investigated experimentally in a cabinet tray dryer. Drying was carried out at $70,75,80$, and $85^{\circ} \mathrm{C}$ with an air velocity $2 \mathrm{~m} / \mathrm{s}$ and relative humidity $30 \%$. The drying data thus obtained were analyzed to get effective diffusivity values by applying the Fick's diffusion model. Effective diffusivity increased with increasing temperature. An Arrhenius relation with an activation energy value of $35.59 \mathrm{~kJ} / \mathrm{mol}$ expressed the effect of temperature on the diffusivity. Also, within the given operating range, the average heat transfer coefficient at the air-product interface is estimated. Experimental data were fitted to ten mathematical models available in the literature. The Midilli $e t$ $a l$. and Wang \& Singh models are given better prediction than the other models and satisfactorily described drying characteristics of red beetroot slices.
\end{abstract}

Keywords: Air temperature, Drying kinetics, Mathematical modeling, Red beetroot, Transport properties

\section{INTRODUCTION}

In developing countries like India, post-harvest losses are more than $30 \%$ due to poor holding capacity, disorganised transport facilities and limited market access. If this high volume of losses is reduced, then it can address the food insecurity situation, a major threat being faced by many developing countries (Alizadeh and Allameh, 2013). Drying is one of the most preferable methods for reducing these post-harvest losses of agricultural products. A considerable amount of moisture content from the products can be removed by drying in order to minimise microbial spoilage and to maintain its desired levels of nutrients. Red beetroot (Beta vulgaris $L$.), which is used as a drying material in present work, is a root vegetable containing several essential nutrients and is a great source of fibre, manganese, potassium, iron, vitamin $\mathrm{C}$ and folate. Besides being used as a food, dried red beetroots find applications in food colorant and medicinal fields (Stintzing and Carle, 2004; Kaur and Kapoor, 2002). Traditionally, red beetroots are dried in open sun. But now-a-days a high volume of the total production of red beetroots is mechanically dried by forced convection. As it requires smaller investment and yields highquality end products (Gokhale and Lele, 2011).

Generally, drying processes are modelled mathematically in order to optimise the existing drying systems or to include a novel process design (Xia and Sun, 2002, Abhishek et al., 2018). Sometimes, drying data obtained experimentally is applied to existing drying equations to choose a sufficiently accurate drying model which is capable of predicting the moisture removal rates and elucidating the performance of drying process of each specific product under the general conditions employed in normal commercial relevant facilities (Sacilik and Elicin, 2006; Erbay and Icier, 2010). The model parameters like transfer coefficients, drying constants of modelling are directly related to the drying conditions i.e., temperature and velocity of the drying medium inside the mechanical dryer.

Although many experimental and mathematical investigations have been carried out in analysing drying characteristics of various fruits and vegetables (Kohli et al., 2018; Sadaka and Atungulu, 2018; Waheed and Komolafe, 2019; Doymaz and Karasu, 2018; Togrul and Pehlivan, 2004; Lopez et al., 2000; Goyal et al., 2006; Midilli and Kucuk, 2003; Akpinar and Bicer, 2005; Abhishek et al., 2019; Doymaz, 2004; Babalis et al., 2006; Lin and Cze, 2018; Nistor et al., 2017; Komolafe et al., 2019), no study has analysed the drying behaviour of red beetroot and estimated its drying parameters such as moisture effective diffusivity, activation energy and heat transfer coefficient during drying.

Hence, the present work aims at determining the effect of the air temperature on drying kinetics of the red beetroot. Also, compared ten thin layer drying equations that best describe its drying kinetics. Further, estimated the transport properties like effective moisture diffusivity, activation energy, heat transfer coefficient.

\section{MATERIALS AND METHODS}

\subsection{Sample preparation}

Fresh good quality red beetroots are obtained from local market in southern state of India. Before drying, red beetroots are washed and hand peeled and cut into rectangular shaped slices having dimensions (60 \pm $0.2) \times(60 \pm 0.2) \times 5 \mathrm{~mm}$. Pre-treatment like blanching, soaking and salting is avoided since it causes loss of water-soluble betalain pigments.

\subsection{Drying equipment and measuring instruments}

A laboratory-scale hot air induced draft convective tray dryer is used to dry the red beetroot slices. The dryer comprises of a drying chamber, heating system, variable speed induced draft fan, rectangular air duct, 
control unit, digital weighing balance and measuring instruments (temperature, humidity, and velocity) as shown in Fig. 1. Drying equipment has a drying capacity of $5 \mathrm{~kg}$ samples per batch, but only $500 \mathrm{~g}$ of beetroot samples are placed in dryer per batch for experimental purposes. Each sample weight is approximately $40 \mathrm{~g}$, which is selected based on the size of the sample and size of the tray. The even distribution of the samples on the trays also plays a major role in the selection of the sample weights. The drying chamber consists of three trays, each about $340 \times 260 \mathrm{~mm}$ size for holding product samples. The heating system consists of three electric heating coils of finned tubular elements consists of $80 \% \mathrm{Ni}$ and $20 \% \mathrm{Cr}$, which is precisely centred in a stainless-steel Ubent tube for heating the ambient air to a required temperature. Air is drawn into the rectangular air duct through these heating coils by a motor driven axial flow induced fan of $2.77 \mathrm{~m}^{3} / \mathrm{s}$ capacity, which is inserted at the end of rectangular duct. The control unit is used for regulating the temperature and velocity of the air across the drying chamber. The digital weighing balance (Accurate electronics ATC-10W-Rear) is placed outside the dryer, which determines and displays sample weight loss continuously during the operation. Temperature of air at the entrance and exit of the drying chamber are measured using T-type thermocouples which are manually controlled by a six-channel temperature indicator with an accuracy of $\pm 0.1^{\circ} \mathrm{C}$. A digital anemometer (Beetech AM-4208) is used to measure the air velocity. Thermo hygrometer is employed to measure the humidity of air at various locations in the drying chamber.

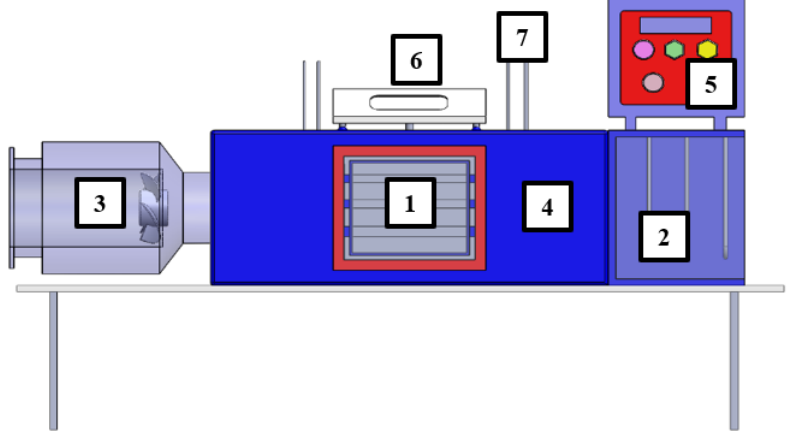

Fig. 1 Bench-scale convective tray dryer.

1- Drying chamber; 2- Heating coils; 3 - Induced draft fan; 4- Air duct; 5- control switches; 6- Digital weighing balance; 7- Measuring instruments

\subsection{Experimental test procedure}

First, drying equipment is operated under no-load conditions to obtain the losses. To study the influence of air temperature on drying kinetics of red beetroot samples, air velocity and humidity in the drying chamber are maintained to a constant value of $2 \mathrm{~m} / \mathrm{s}$ and $30 \%$ respectively and air temperature is varied in the range of $70{ }^{\circ} \mathrm{C}$ to $85^{\circ} \mathrm{C}$. For each experiment, dryer should reach steady state condition. After the dryer has reached steady state conditions, $500 \mathrm{~g}$ of red beetroot slices are uniformly kept in the three trays provided inside the drying chamber. The sample weight loss is recorded during drying experiments at every $10 \mathrm{~min}$ intervals. This drying operation is continued until no change in the weight of the product is noticed for three successive readings. All experiments are repeated twice.

\subsection{Experimental uncertainty}

Table 1 Uncertainties of the parameters during the drying of red beetroot

\begin{tabular}{|l|c|}
\hline \multicolumn{1}{|c|}{ Parameter } & Uncertainty \\
\hline Temperature between trays & $\pm 0.4{ }^{\circ} \mathrm{C}$ \\
\hline Velocity measurement & $\pm 0.2 \mathrm{~m} / \mathrm{s}$ \\
\hline Mass loss measurement & $\pm 0.01 \mathrm{~g}$ \\
\hline Relative humidity & $\pm 2 \%$ \\
\hline
\end{tabular}

Errors in the experiments can arise from instrument selection, condition, calibration, environment and human factors (Midilli, 2001b). During the measurements of the parameters, the uncertainties occurred were presented in Table 1.

\section{MATHEMATICAL MODELING}

\subsection{Drying kinetics}

The moisture transfer from red beetroot to surrounding hot air is mathematically analogous to the flow of heat from a hot body immersed in a cool fluid that is represented by Newton's law of cooling (Gokhale and Lele, 2011). Therefore, the drying rate is proportional to the difference in moisture content between the material being dried and the equilibrium moisture content $\left(X_{e}\right)$ which is dependent on the drying air conditions.

The moisture ratio $\emptyset$ and drying rate $D R$ of red beetroot slices during the thin-layer drying experiments were calculated using Eq. (1) and Eq. (2) (Midilli, 2001a; Akpinar, 2002)

$$
\begin{gathered}
\phi=\frac{X_{\tau}-X_{e}}{X_{o}-X_{e}} \\
D R=\frac{m_{d}}{A_{s}} \frac{\Delta X}{\Delta \tau}
\end{gathered}
$$

Table 2 Selected thin-layer drying models for describing red beetroot drying data.

\begin{tabular}{|c|l|c|}
\hline Model Name & \multicolumn{1}{|c|}{ Thin-layer drying model } & References \\
\hline Newton model & $\phi=e^{(-k \tau)}$ & Lewis, (1921) \\
\hline Page model & $\phi=e^{\left(-k \tau^{n}\right)}$ & Page, (1949) \\
\hline $\begin{array}{c}\text { Modified Page } \\
\text { model }\end{array}$ & $\phi=e^{(-k \tau)^{n}}$ & $\begin{array}{c}\text { Overhults } \text { et } \\
\text { al., (1973) }\end{array}$ \\
\hline $\begin{array}{c}\text { Henderson and } \\
\text { Pabis model }\end{array}$ & $\phi=a e^{(-k \tau)}$ & $\begin{array}{c}\text { Henderson } \\
\text { and Pabis, } \\
(1961)\end{array}$ \\
\hline $\begin{array}{c}\text { Logarithmic } \\
\text { model }\end{array}$ & $\phi=a e^{(-k \tau)}+c$ & $\begin{array}{c}\text { Chandra and } \\
\text { Singh, (1995) }\end{array}$ \\
\hline $\begin{array}{c}\text { Two-term } \\
\text { model }\end{array}$ & $\phi=a e^{\left(-k 1^{2}\right)}+b e^{\left(-k_{2} \tau\right)}$ & $\begin{array}{c}\text { Henderson, } \\
(1974)\end{array}$ \\
\hline $\begin{array}{c}\text { Two-term } \\
\text { exponential } \\
\text { model }\end{array}$ & $\phi=a e^{(-k \tau)}+(1-a) e^{(-k a \tau)}$ & $\begin{array}{c}\text { Sharaf-Elden } \\
\text { et al., (1980) }\end{array}$ \\
\hline $\begin{array}{c}\text { Wang and } \\
\text { Singh model }\end{array}$ & $\phi=1+a \tau+b \tau^{2}$ & $\begin{array}{c}\text { Wang and } \\
\text { Singh, (1978) }\end{array}$ \\
\hline Verma model & $\phi=a e^{(-k \tau)}+(1-a) e^{(-g \tau)}$ & $\begin{array}{c}\text { Verma } \text { et al., } \\
(1985)\end{array}$ \\
\hline Midilli model & $\phi=a e^{\left(-k \tau^{n}\right)}+b \tau$ & $\begin{array}{c}\text { Midilli } \text { et al., } \\
(2002)\end{array}$ \\
\hline
\end{tabular}

Drying curves were fitted to ten well-known thin-layer drying models in Table 2. to select the best suited model for describing the drying characteristics of red beetroot slices. Non-linear square regression analysis was performed using MATLAB 18.1 (MathWorks, Inc., 1984, Natick, USA) computer program. The goodness of the fit can be checked with different statistical indicators such as Correlation coefficient $(R)$, Coefficient of determination $\left(R^{2}\right)$, Chi-square $\left(\chi^{2}\right)$, Sum of Squares for Error (SSE), Root Mean Square Error (RMSE), Mean Absolute Percentage Error $(M A P E)$ and Mean Bias Error $(M B E)$ respectively. But a minimum of two indicators are required to decide the goodness of the fit. Of all these statistical indicators, $\mathrm{R}^{2}$ and RMSE are two regression parameters majorly employed by researchers. Hence, in the present work, the goodness of the fit was determined by using the coefficient of 
determination $\left(R^{2}\right)$ and root mean square error (RMSE) (Wang et al., 2007a, Vedavathi et al., 2019, Kiran et al., 2019, Midilli et al., 2002).

These parameters can be calculated by Eq. (3) \& Eq. (4). The higher values of $R^{2}$ and the lower values of $R M S E$ are chosen as the criteria for the goodness of fit in the present study (Yaldiz et al., 2001, Wang et al., 2007b, Lahsasni et al., 2004, Abhishek et al., 2019).

$$
\begin{aligned}
& R^{2}=1-\frac{\sum_{i=1}^{N}\left(\phi_{\text {pre }, i}-\phi_{\mathrm{exp}, i}\right)^{2}}{\sum_{i=1}^{N}\left(\phi_{\mathrm{exp}, i}-\phi_{\text {avg }}\right)^{2}} \\
& R M S E=\sqrt{\left[\frac{1}{N} \sum_{i=1}^{N}\left(\phi_{\text {pre }, i}-\phi_{\mathrm{exp}, i}\right)^{2}\right]}
\end{aligned}
$$

\subsection{Effective moisture diffusivity}

It is the important drying parameter that represents the conductive term of all moisture transfer mechanisms (Srikiatden and Roberts, 2006). It gives the internal mass transfer in the red beetroot. Diffusion of moisture within the red beetroot during drying may occur as an amalgam of capillary flow, Knudsen flow, molecular diffusion, hydrodynamic flow and surface diffusion.

Hence it is significant to compute effective moisture diffusivity. From the drying data analysis, it was recognized that the air-drying of red beetroot didn't consist of constant rate drying period. Hence, Fick's II law of unsteady state diffusion in Eq. (8) can be used to interpret the experimental results.

For an infinite slab and uniform initial moisture concentration, Crank (1975) proposed analytical solution Eq. (9) for Eq. (8) with the following suitable boundary conditions Eq. (5) - Eq. (7).

$$
\begin{aligned}
& \tau=0 \& 0<z<L \Rightarrow X=X_{o} \\
& \tau>0 \& z=0 \Rightarrow \frac{d X}{d \tau}=0 \\
& \tau>0 \& z=L \Rightarrow X=X_{e} \\
& \frac{\partial X}{\partial \tau}=D_{e f f} \frac{\partial^{2} X}{\partial z^{2}} \\
& \phi=\frac{8}{\pi^{2}} \sum_{n=0}^{\infty} \frac{1}{(2 n+1)^{2}} e^{\left(-(2 n+1)^{2} \pi^{2} \frac{D_{e f f}}{4 L^{2}} \tau\right)}
\end{aligned}
$$

$D_{\text {eff }}$ mainly varies with internal conditions like the product's temperature, the moisture content and the structure. By considering a very low thickness to width ratio, the sample was assumed to be infinite slab. For longer drying periods, the Eq. (9) can be reduced to Eq. (10). From Eq. (10), it is seen that the moisture ratio with respect to time data is provided.

The $D_{\text {eff }}$ is calculated at all moisture ratio values for each temperature. As the calculation involves complexity, MATLAB 18.1 is employed to calculate $\mathrm{D}_{\text {eff }}$ at all moisture values for each temperature. The diffusion coefficient is averaged for each drying temperature using Eq. (11).

$$
\begin{gathered}
\ln (\phi)=\ln \left(\frac{8}{\pi^{2}}\right)-\pi^{2} \frac{D_{\text {eff }}}{4 L^{2}} \tau \\
D_{\text {eff }, \text { avg }}=\frac{\int_{X_{O}}^{X_{e}} D_{e f f}(X) d X}{\int_{X_{O}}^{X_{e}} d X}
\end{gathered}
$$

\subsection{Activation energy}

The activation energy is another important drying parameter, that indicates the energy level of water molecules for moisture diffusion and evaporation (Chen et al., 2012). The dependency between $D_{\text {eff }}$ and temperature can be indicated by an Arrhenius relationship Eq. (12).

$$
D_{\text {eff }}=D_{o} \exp \left(\frac{-E_{a}}{R(T+273.15)}\right)
$$

The value of $E_{a}$ represents the sensibility of the diffusivity against temperature. The greater value of $E_{a}$ means more sensibility of $D_{e f f}$ to temperature (Kaymak-Ertekin, 2002). Here, $D_{o}$ is the pre-exponential factor of the Arrhenius equation $\left(\mathrm{m}^{2} / \mathrm{s}\right)$ that is generally defined as the reference diffusion coefficient at infinitely high temperature. Thus, the activation energy of red beetroot slices can be determined from the slope obtained by plotting $\ln \left(D_{\text {eff }}\right)$ versus the reciprocal of absolute drying air temperature.

\subsection{Heat transfer coefficient}

The average convective heat coefficients $\left(k_{h}\right)$ at the interface of air-red beetroot slices are determined by Eq. (13) (Gokhale and Lele, 2011).

$k_{h}=\frac{\dot{m}(\Delta h)}{A\left(T_{a}-T_{s}\right)}$

\section{RESULTS AND DISCUSSIONS}

\subsection{Drying curves and drying rate curves}

The drying of red beetroot slices is performed using convective tray dryer. The drying air temperatures considered are $70,75,80$ and $85^{\circ} \mathrm{C}$ for a specified air velocity of $2 \mathrm{~m} / \mathrm{s}$, relative humidity $30 \%$ and product thickness $4 \mathrm{~mm}$. During the drying process, equilibrium moisture content of the beetroot with the drying air is said to be attained, where there is no further change in the weight of the red beetroot is noticed. For modelling, beetroot slices are assumed to be infinite slabs and the correlations for the moisture content are specified by Velic et al., (2004) are used. Beetroot slices of average initial moisture content $9.55(\mathrm{~kg} \mathrm{w} / \mathrm{kg} \mathrm{ds})$ is used and is dried to 0.03 ( $\mathrm{kg} \mathrm{w} / \mathrm{kg} \mathrm{ds}$ ).

The variation of red beetroot moisture content and drying rate with time for different inlet air temperatures are plotted in Figs. 2 and 3. From Fig 2 , it can be seen that moisture content decreases monotonically as a function of time. Also, it can be seen that as the inlet air temperature increases, the rate of decrease of moisture content is steep, which signifies the influence of the temperature. Drying time decreases from $420 \mathrm{~min}$ at $70^{\circ} \mathrm{C}$ air inlet temperature to $280 \mathrm{~min}$ at $85^{\circ} \mathrm{C}$ air inlet temperature.

Rate of drying can be interpreted by plotting the drying rate as a function of moisture content of the sample given by Eq. (2). Fig. 3 illustrates the variation of drying rate $\left(\mathrm{kg} \mathrm{w} / \mathrm{min} \times \mathrm{m}^{2}\right)$ with moisture content for the sample at different temperatures. It can be seen that as the moisture content decreases the rate of drying also decreases and this variation doesn't follow a specific trend. For moderate temperatures, the rate of drying increases and then decreases as the moisture content decreases. At moderate temperatures, the reduction in the moisture content of the sample induces a moisture gradient between the surface and the sample interior core. As a result, the drying rate initially increases and then decreases due to lack of moisture on the surface of the beetroot. If the migration speed of molecules within the sample and the air are equal then the variation would have been linear. But due to the variation in the migration speeds of water molecules the trend is nonlinear. At higher temperatures drying rate decreases as the moisture content decreases. 


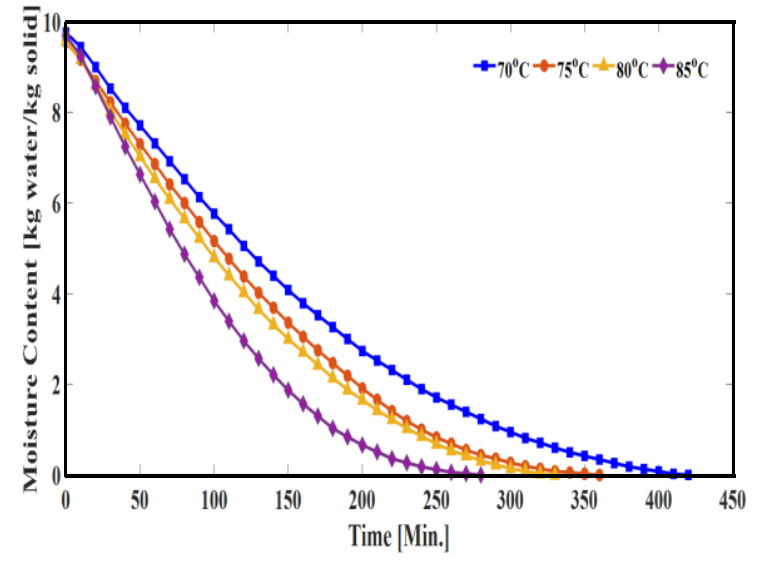

Fig. 2 Moisture content of beetroot slices as a function of time at different drying temperatures

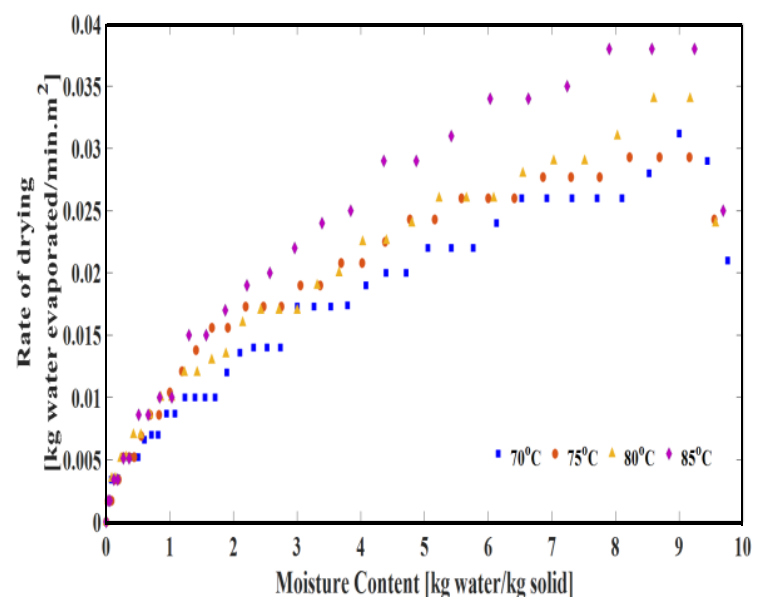

Fig. 3 Drying rate curves of beetroot slices at different temperatures.

\subsection{Evaluation of transport properties during drying}

Non-linear regression analysis is performed using least square methods in MATLAB-2018 to fit the experimental data to pre-existing models from the literature described in Table 2 . The coefficients RMSE and $\mathrm{R}^{2}$ are evaluated and tabulated in Table 3. The model with lowest RMSE and highest $\mathrm{R}^{2}$ describes the drying process of beetroot. From Table 3, it can be seen that mathematical models described by Wang \& Singh have the RMSE and $\mathrm{R}^{2}$ in the range of 0.0057 to 0.011 and 0.9989 to 0.9998 , and Midilli et al., have the RMSE and $\mathrm{R}^{2}$ in the range of 0.004 to 0.01 and 0.9991 to 0.9998 respectively for the specified temperatures.

For better visualization of variation of moisture ratio as a function of time at varying inlet air temperatures, logarithmic variation of moisture ratio $[\ln (\phi)]$ with time was used in pieces of literatures (Gokhale and Lele, 2011, Doymaz, 2007). In the present work, Figs. 4-5, describes the variation of $\ln (\varnothing)$ with time. The best suitable models that describe the drying process i.e., models $8 \& 10$ in Table 2, are plotted. The plots obtained are in accordance with that of Gokhale and Lele, (2011) and Doymaz, (2007).

Drying time is influenced by the internal mass transfer rate when the rate of drying decreases with a decrease in moisture content as shown in Fig. 3 . The falling rate drying processes is analysed by Fick's law of diffusion. The general solution for the present geometry of the beetroot is given by Crank (1975) as stated in Eq. (9). The general solution as such is an infinite series that requires a series convergence study, but for a higher

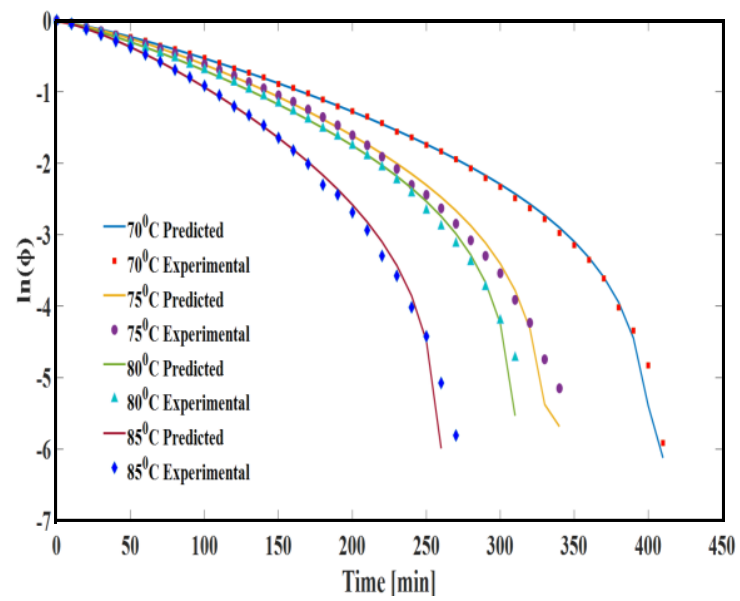

Fig. 4 Experimental and predicted data obtained by Midilli model.

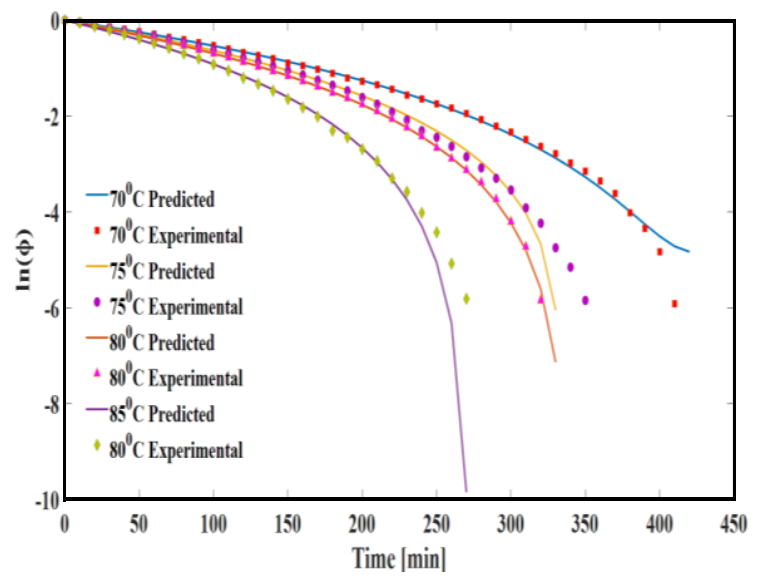

Fig. 5 Experimental and predicted data obtained by Wang and Singh model.

drying time equation can be simplified by considering the first term in the series as stated in Senadeera et al., (2003).

The simplified expression is given by Eq. (10). From Figs. $4 \& 5$, it can be seen that variation of $\ln (\phi)$ with time is not linear which concludes that effective diffusivity $\mathrm{D}_{\text {eff }}$ is not constant and has to be obtained from Eq. (10), which is a typical feature observed in porous materials. The variation of the effective diffusivity $\mathrm{D}_{\text {eff }}$ with moisture ratio is shown in Fig. 6. It can be seen that $D_{\text {eff }}$ increases with a decrease in moisture ratio and further, it can be seen that $\mathrm{D}_{\text {eff }}$ increases with an increase in drying air temperature. The dependence of the $\mathrm{D}_{\text {eff }}$ on moisture content is due to the complex phenomenon that governs the transport of moisture during drying.

The average effective moisture diffusivity $\mathrm{D}_{\text {eff }}$ are found to be $3.11 \times 10^{-8}, 3.89 \times 10^{-8}, 4.03 \times 10^{-8} \& 5.48 \times 10^{-8} \mathrm{~m}^{2} / \mathrm{min}$ for $70,75,80$ and $85^{\circ} \mathrm{C}$ respectively. With an assumption that the temperature distribution within the beetroot is uniform, the convective heat transfer coefficient between air and beetroot was calculated using Eq. (13). Fig. 7. illustrates the variation of effective diffusivity $\mathrm{D}_{\text {eff }}$ and the heat transfer coefficient with temperature. It can be seen that the heat transfer coefficient decreases with an increase in drying temperature and variation is vice versa for $\mathrm{D}_{\text {eff }}$ viz., moisture effective diffusivity increases with an increase in drying temperature. Since the moisture evaporation rate at all drying temperature is similar, therefore change in heat transfer coefficient is small at all drying temperatures. It can be concluded that $\mathrm{D}_{\text {eff }}$ is directly proportional to beetroot temperature, which in turn depends on the drying air temperature. 
The temperature dependence of $\mathrm{D}_{\text {eff }}$ can be described by Arrhenius-type of the relationship as given in Eq. (12). The activation energy $\mathrm{E}_{\mathrm{a}}$ is calculated from the slope of the plot on $\ln \left(D_{\text {eff }}\right)$ vs $1 / T$ in Fig. 8. Calculations for $\mathrm{E}_{\mathrm{a}} \& \mathrm{D}_{\mathrm{o}}$ are shown below.

Slope from the plot Fig. 8 is, $m=-E_{a} / R=-4258$

Therefore, $\mathrm{E}_{\mathrm{a}}=4258 \times 8.314 \mathrm{~J} / \mathrm{mol}=35.59 \mathrm{~kJ} / \mathrm{mol}$
From the curve fitting, $\left(\mathrm{R}^{2}=0.9216\right)$

we get $\ln \left(\mathrm{D}_{\mathrm{o}}\right)=-4.878 \Rightarrow D_{o}=7.61 \times 10^{-3} \mathrm{~m}^{2} / \mathrm{min}$

$\mathrm{D}_{\mathrm{o}}$ which is pre-exponential factor of Arrhenius equation, represents the diffusivity value for infinite moisture content in the product.

The value of $E_{a}$ is found to be $35.6 \mathrm{~kJ} / \mathrm{mol}$. The value obtained in this study is in close range of $15-40 \mathrm{~kJ} / \mathrm{mol}$ with various foods reported by Rizvi (1995).

Table 3 Results of statistical analyses on the modelling of moisture content and drying time

\begin{tabular}{|c|c|c|c|c|}
\hline \multirow{2}{*}{ Model } & \multirow{2}{*}{$\begin{array}{c}\mathrm{T} \\
\left({ }^{\circ} \mathrm{C}\right)\end{array}$} & \multicolumn{2}{|c|}{ Statistics } & \multirow{2}{*}{ Coefficients } \\
\hline & & $R^{2}$ & $R M S E$ & \\
\hline \multirow{4}{*}{ Newton } & 70 & 0.9739 & 0.0498 & $k=6.429 \times 10^{-3}$ \\
\hline & 75 & 0.9637 & 0.06072 & $\mathrm{k}=7.522 \times 10^{-3}$ \\
\hline & 80 & 0.9715 & 0.05283 & $k=8.082 \times 10^{-3}$ \\
\hline & 85 & 0.9680 & 0.05765 & $\mathrm{k}=1.019 \times 10^{-2}$ \\
\hline \multirow{4}{*}{ Page } & 70 & 0.9971 & 0.01647 & $k=1.196 \times 10^{-3} ; n=1.323$ \\
\hline & 75 & 0.9960 & 0.02018 & $k=9.547 \times 10^{-3} ; n=1.409$ \\
\hline & 80 & 0.9961 & 0.01947 & $k=1.499 \times 10^{-3} ; n=1.339$ \\
\hline & 85 & 0.9978 & 0.01511 & $k=1.544 \times 10^{-3} ; n=1.397$ \\
\hline \multirow{4}{*}{ Modified page } & 70 & 0.9971 & 0.01647 & $k=6.194 \times 10^{-3} ; n=1.323$ \\
\hline & 75 & 0.9960 & 0.02018 & $k=7.186 \times 10^{-3} ; n=1.409$ \\
\hline & 80 & 0.9961 & 0.01947 & $k=7.776 \times 10^{-3} ; n=1.339$ \\
\hline & 85 & 0.9978 & 0.01511 & $k=9.718 \times 10^{-3} ; n=1.397$ \\
\hline \multirow{4}{*}{$\begin{array}{l}\text { Henderson } \\
\text { and Pabis }\end{array}$} & 70 & 0.9820 & 0.4131 & $a=1.089 ; k=0.00698$ \\
\hline & 75 & 0.9741 & 0.05123 & $a=1.103 ; k=0.00826$ \\
\hline & 80 & 0.9796 & 0.04468 & $a=1.089 ; k=0.00878$ \\
\hline & 85 & 0.9778 & 0.048 & $a=1.102 ; k=0.01115$ \\
\hline \multirow{4}{*}{ Logarithmic } & 70 & 0.9985 & 0.0119 & $a=1.229 ; k=4.663 \times 10^{-3} ; c=-0.1964$ \\
\hline & 75 & 0.9963 & 0.01934 & $a=1.278 ; k=5.194 \times 10^{-3} ; c=-0.2371$ \\
\hline & 80 & 0.9985 & 0.01202 & $a=1.252 ; k=5.649 \times 10^{-3} ; c=-0.2216$ \\
\hline & 85 & 0.9959 & 0.02072 & $a=1.231 ; k=7.615 \times 10^{-2} ; c=-0.1826$ \\
\hline \multirow{4}{*}{ Two term } & 70 & 0.9983 & 0.01253 & $a=4.978 ; k_{1}=0.00296 ; b=-3.972 ; k_{2}=0.00238$ \\
\hline & 75 & 0.9935 & 0.02564 & $a=24.3 ; k_{1}=0.01404 ; b=-23.29 ; k_{2}=0.001453$ \\
\hline & 80 & 0.9945 & 0.02313 & $a=12.71 ; k_{1}=0.01437 ; b=-11.7 ; k_{2}=0.01528$ \\
\hline & 85 & 0.9957 & 0.02115 & $a=61.92 ; k_{1}=0.01859 ; b=-60.91 ; k_{2}=0.01883$ \\
\hline \multirow{4}{*}{$\begin{array}{l}\text { Two-term } \\
\text { exponential }\end{array}$} & 70 & 0.9957 & 0.0203 & $a=1.857 ; k=0.009268$ \\
\hline & 75 & 0.9928 & 0.02707 & $a=1.918 ; k=0.01116$ \\
\hline & 80 & 0.9942 & 0.02384 & $a=1.865 ; k=0.0117$ \\
\hline & 85 & 0.9954 & 0.0219 & $a=1.922 ; k=0.01511$ \\
\hline \multirow{4}{*}{$\begin{array}{l}\text { Wang and } \\
\text { Singh }\end{array}$} & 70 & 0.9996 & 0.00577 & $a=-0.004682 ; b=5.524 e^{-06}$ \\
\hline & 75 & 0.9990 & 0.01013 & $a=-0.005415 ; b=7.248 e^{-06}$ \\
\hline & 80 & 0.9998 & 0.00419 & $a=-0.005854 ; b=8.564 e^{-06}$ \\
\hline & 85 & 0.9989 & 0.01081 & $a=-0.007357 ; b=1.353 e^{-05}$ \\
\hline \multirow{4}{*}{ Verma et al. } & 70 & 0.9965 & 0.01819 & $a=30.79 ; k=0.01159 ; g=0.01189$ \\
\hline & 75 & 0.9942 & 0.02436 & $a=34.03 ; k=0.0143 ; g=0.01467$ \\
\hline & 80 & 0.9951 & 0.0218 & $a=14.23 ; k=0.01444 ; g=0.01527$ \\
\hline & 85 & 0.9964 & 0.01921 & $a=48.19 ; k=0.01925 ; g=0.01959$ \\
\hline \multirow{4}{*}{ Midilli et al. } & 70 & 0.9998 & 0.00409 & $a=0.991 ; k=1.797 \times 10^{-3} ; b=-1.52 \times 10^{-4} ; n=1.22$ \\
\hline & 75 & 0.9991 & 0.00963 & $a=0.9823 ; k=1.26 \times 10^{-3} ; b=-1.66 \times 10^{-4} ; n=1.33$ \\
\hline & 80 & 0.9996 & 0.00615 & $a=0.994 ; k=2.489 \times 10^{-3} ; b=-2.35 \times 10^{-4} ; n=1.21$ \\
\hline & 85 & 0.9995 & 0.00700 & $a=0.9896 ; k=1.947 \times 10^{-3} ; b=-1.5 \times 10^{-4} ; n=1.33$ \\
\hline
\end{tabular}




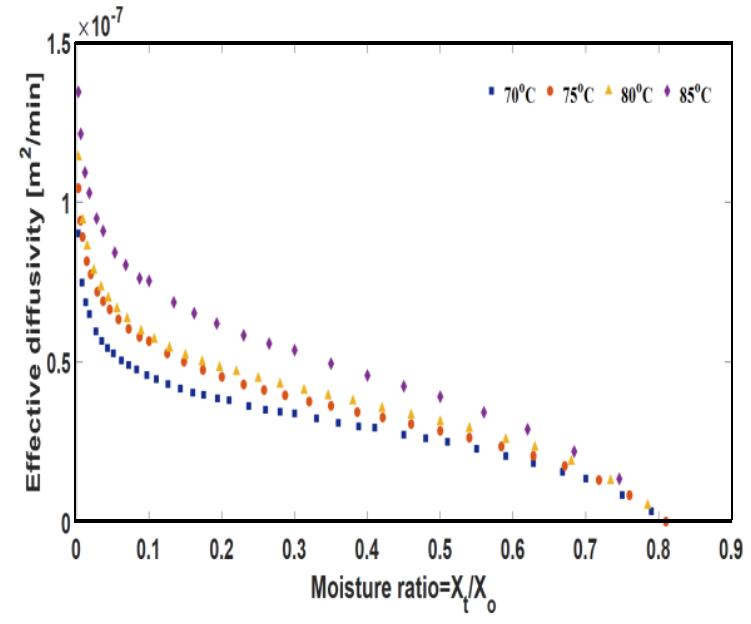

Fig. 6 Variation of $D_{\text {eff }}$ as a function of moisture ratio for different drying temperatures

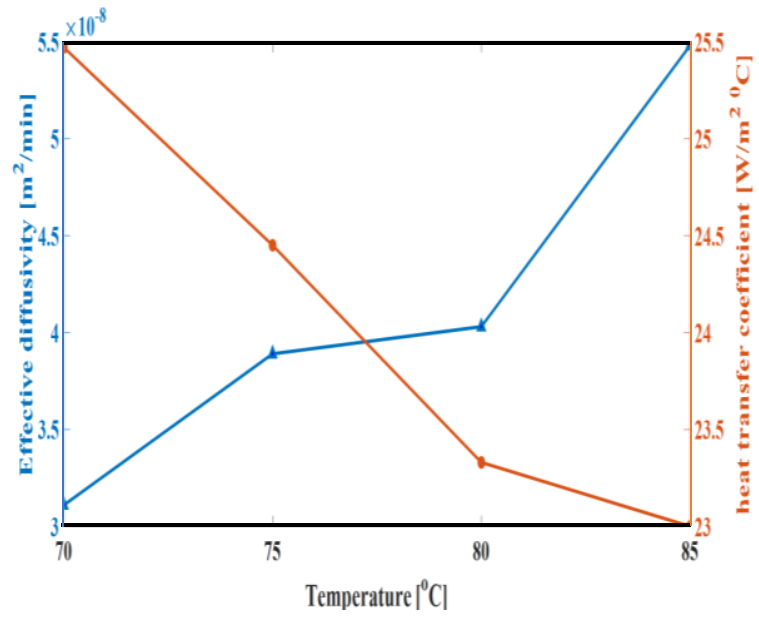

Fig. 7 Effect of air temperature on the effective moisture diffusivity and heat transfer coefficients.

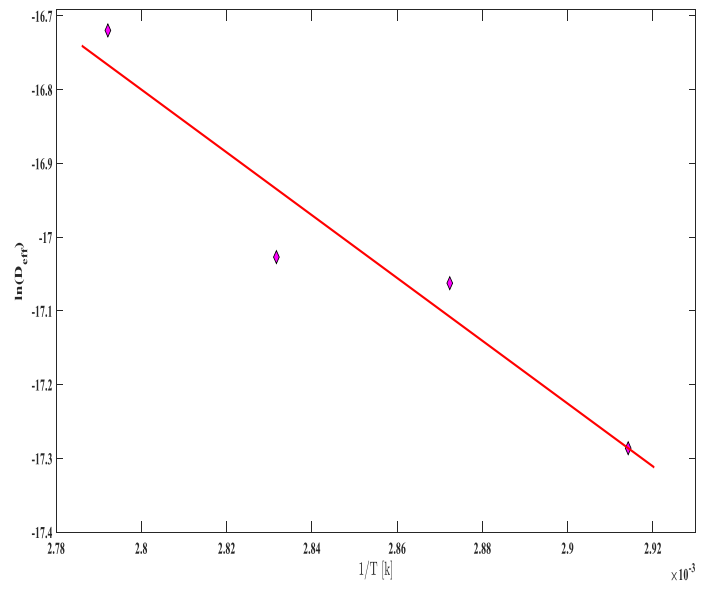

Fig. 8 Temperature dependence of $D_{\text {eff }}$ by Arrhenius relation

\section{CONCLUSIONS}

The drying kinetics of beetroot slices are investigated in an induced draft convective tray dryer, at constant air velocity of $2.0 \mathrm{~m} / \mathrm{s}$ and at $70,75,80$ and $85^{\circ} \mathrm{C}$ air temperatures respectively. The following conclusions can be drawn from this work.
(1) Heat transfer coefficient and average effective diffusion coefficient at all considered temperatures are obtained.

(2) During beetroot drying, only initial and falling rate periods are occurred, with the absence of a constant-rate period, like most agricultural products.

(3) The effective moisture diffusivity values calculated for drying of beetroot in temperature $70-85^{\circ} \mathrm{C}$ are ranged from $3.11 \times 10^{-8} \mathrm{~m}^{2} / \mathrm{min}$ to $5.48 \times 10^{-8} \mathrm{~m}^{2} / \mathrm{min}$.

(4) It is found that higher drying temperatures are corresponds with shorter drying time.

(5) The results also suggest that with increase in air temperature, heat transfer coefficient decreases and effective diffusivity coefficient increases.

(6) The Midilli et al. and Wang \& Singh drying models were found to the most suitable models to describe beetroot drying in thinlayers by hot air.

\section{NOMENCLATURE}

Deff effective moisture diffusivity $\left(\mathrm{m}^{2} / \mathrm{min}\right)$

Do pre-exponential factor of Arrhenius equation $(\mathrm{kJ} / \mathrm{mol})$

$\mathrm{Ea}_{\mathrm{a}} \quad$ activation energy $(\mathrm{kJ} / \mathrm{mol})$

exp,i $\quad i^{\text {th }}$ experimental moisture ratio value

$\mathrm{k}_{\mathrm{h}} \quad$ heat transfer coefficient

$\mathrm{N}$ number of observations

pre, $\mathrm{i} \quad \mathrm{i}^{\text {th }}$ predicted moisture ratio value

$\mathrm{R}^{2} \quad$ coefficient of determination

RMSE root mean square error

$\mathrm{R} \quad$ universal gas constant $(8.314 \mathrm{~J} / \mathrm{mol} \mathrm{K})$

$\mathrm{T} \quad$ temperature $\left({ }^{\circ} \mathrm{C}\right)$

$\mathrm{X}_{\tau} \quad$ moisture content at any time $(\mathrm{kg} \mathrm{w} / \mathrm{kg} \mathrm{ds})$

$\mathrm{X}_{\mathrm{e}} \quad$ equilibrium moisture content $(\mathrm{kg} \mathrm{w} / \mathrm{kg} \mathrm{ds})$

$\mathrm{X}_{\mathrm{o}} \quad$ initial moisture content $(\mathrm{kg} \mathrm{w} / \mathrm{kg} \mathrm{ds})$

Greek Symbols

$\tau \quad$ drying time (min)

$\varnothing \quad$ fractional moisture ratio

\section{REFERENCES}

Abhishek, D., Ramakrishna, K., and Naveen, P., 2018, “A panorama of ideas in the adoption of an effective and efficient drying technique for an agricultural produce", International Journal of Mechanical and Production Engineering Research and Development, 8(6), 955-962. https://dx.doi.org/10.24247/ijmperddec201896

Abhishek, D., Ramakrishna, K., and Naveen, P., 2019, "Method for determining the appropriate thin layer drying model for a feedstock", International Journal of Recent Technology and Engineering, 8(3), 3627-3632. https://dx.doi.org/10.35940/ijrte.C53350.098319

Abhishek, D., Ramakrishna, K., and Naveen, P., 2019, "Experimental investigation and mathematical modeling of convective drying kinetics of white radish", Frontiers in Heat and Mass Transfer, 13, 21, 1-7. https://dx.doi.org/10.5098/hmt.13.21

Akpinar, E. K. and Bicer, Y., 2005, "Modelling of the drying of eggplants in thin-layers", International Journal of Food Science and Technology, 40(3), 273-281. https://doi.org/10.1111/j.1365-2621.2004.00886.x

Akpinar, K. E., 2002, "The development of a cyclone type dryer for agricultural products", Ph.D. Thesis, Firat University, Elazig, Turkey.

Alizadeh, M. R. and Allameh, A., 2013, "Evaluating rice losses in various harvesting practices", International Research Journal of Applied and Basic Sciences, 4(4), 894-901. 
Babalis, S. J., Papanicolaou, E., Kyriakis, N., Belessiotis, V. G., 2006, "Evaluation of thin-layer drying models for describing drying kinetics of figs (Ficus carica)", Journal of Food Engineering, 75(2), 205-214. https://doi.org/10.1016/i.jfoodeng.2005.04.008

Chandra, P. K., and Singh, R. P., 1995, Applied Numerical Methods for Food and Agricultural Engineers, CRC Press, Boca Raton, FL. 163-167.

Chen, D., Zheng, Y., and Zu, X., 2012, "Determination of effective moisture diffusivity and drying kinetics for poplar sawdust by thermogravimetric analysis under isothermal condition", Bioresource Technology, 107, 451-455.

https://doi.org/10.1016/j.biortech.2011.12.032

Crank J., 1975, The Mathematics of Diffusion, $2^{\text {nd }}$ ed., Clarendon Press, UK.

Doymaz, I., 2004, "Convective air-drying characteristics of thin layer carrots", Journal of Food Engineering, 61(3), 359-364.

https://doi.org/10.1016/S0260-8774(03)00142-0

Doymaz, I., and Karasu, S., 2018, "Effect of air temperature on drying kinetics, colour changes and total phenolic content of sage leaves (Salvia officinalis)", Quality Assurance and Safety of Crops and Foods, 10(3), 269-276. https://doi.org/10.3920/QAS2017.1257

Doymaz, I., 2007, “Air-drying characteristics of tomatoes", Journal of Food Engineering, 78(4), 1291-1297.

https://doi.org/10.1016/j.jfoodeng.2005.12.047

Erbay, Z. and Icier, F., 2010, "A review of thin layer drying of foods: theory, modelling and experimental results", Critical Reviews in Food Science and Nutrition, 50(5), 441-464.

https://doi.org/10.1080/10408390802437063

Gokhale, S. V., and Lele, S. S., 2011, "Dehydration of red beet root (Beta vulgaris) by hot air drying: Process optimization and mathematical modeling", Food Science and Biotechnology, 20(4), 955-964.

https://doi.org/10.1007/s10068-011-0132-4

Goyal, R. K., Kingsly, A. R. P., Manikantan, M. R., and Ilyas, S. M., 2006, "Thin-layer drying kinetics of raw mango slices", Biosystems Engineering, 95(1), 43-49.

https://doi.org/10.1016/j.biosystemseng.2006.05.001

Henderson, S. M., and Pabis, S., 1961, "Grain drying theory I: Temperature effect on drying coefficient", Journal of Agricultural Engineering Research, 6, 169-174.

Henderson, S. M., 1974, "Progress in developing the thin layer drying equation", Transactions of the ASAE, 17(6), 1167-1168.

https://doi.org/10.13031/2013.37052

Kaur, C. and Kapoor, H. C., 2002, "Anti-oxidant activity and total phenolic content of some Asian vegetables", International Journal of Food Science and Technology, 37(2), 153-161.

https://doi.org/10.1046/j.1365-2621.2002.00552.x

Kaymk-Ertekin, F., 2002, "Drying and rehydrating kinetics of green and red peppers", Journal of Food Science, 67, 168-175.

https://doi.org/10.1111/j.1365-2621.2002.tb11378.x

Kiran Naik, B., Muthukumar, P., and Bhattacharyya, C., 2019, “Thermal modelling and parametric investigations on coupled heat and mass transfer processes occurred in a packed tower", Heat and Mass Transfer, 55, 627-644. https://doi.org/10.1007s00231-018-2440-1

Kohli, D., Shahi, N. C., and Kumar, A., 2018, "Drying kinetics and activation energy of Asparagus root for different methods of drying", Current Research in Nutrition and Food Science, 6(1), 191-202. http://dx.doi.org/10.12944/CRNFSJ.6.1.22
Komolafe, A. C., Ojediran, O. J., Ajao, F. O., Dada, A. O., Afolabi, Y. T., Oluwaleye, O. I., Alake, S. A., 2019, "Modelling of moisture diffusivity during solar drying of locust beans with thermal storage material under forced and natural convection mode", Case Studies in Thermal Engineering, 15, 100542

https://doi.org/10.1016/j.csite.2019.100542

Lahsasni, S., Kouhila, M., Mahrouz, M., and Jaouhari, J.T., 2004, "Drying kinetics of prickly pear fruit (Opuntia ficus indica)", Journal of Food Engineering, 61(2), 173-179.

https://doi.org/10.1016/S0260-8774(03)00084-0

Lewis, W. K., 1921, "The rate of drying of solid materials", $I \& E C$ Symposium of drying, 3(5), 42.

Lin, C. B., and Cze, C. Y., 2018, "Drying kinetics and optimization of pectin extraction from banana peels via response surface methodology", MATEC Web of Conference, 152, 01002.

https://doi.org/10.1051/matecconf/201815201002

Lopez, A., Iguaz, A., Esnoz, A., and Virseda, P., 2000, "Thin-layer drying behaviour of vegetable wastes from wholesale market", Drying Technology, 18(4-5), 995-1006.

https://doi.org/10.1080/07373930008917749

Midilli, A., 2001a, "Determination of pistachio drying behavior and conditions in a solar drying system", International Journal of Energy Research, 25(8), 715-725. https://doi.org/10.1002/er.715

Midilli, A., 2001b, "Wastewater distillation by using natural vacuum technique", Ph.D. Thesis, Karadeniz Technical University, Trabzon, Turkey.

Midilli, A. and Kucuk, H., 2003, "Mathematical modelling of thin layer drying of pistachio by using solar energy", Energy Conversion and Management, 44(7), 1111-1122.

https://doi.org/10.1016/S0196-8904(02)00099-7

Midilli, A., Kucuk, H., and Yapar, Z., 2002, "A new model for singlelayer drying", Drying Technology, 20(7), 1503-1513.

https://doi.org/10.1081/DRT-120005864

Nistor, O. V., Seremet, L., Andronoiu, D. G., Rudi, L. and Botez, E., 2017, "Influence of different drying methods on the physiochemical properties of red beetroot (Beta vulgaris L. Var. Cylindra)", Food Chemistry, 236, 59-67. https://doi.org/10.1016/j.foodchem.2017.04.129

Overhults, D. G., White, G. M., Hamilton, H. E., and Ross, I. J., 1973, "Drying soybeans with heated air", Transactions of the ASAE, 16(1), 112-113. https://doi.org/10.13031/2013.37459

Page, G. E., 1949, "Factors influencing the maximum rate of air-drying shelled corn in thin-layers", M. S. Thesis, Purdue University, West Lafayette, Indiana.

Rizvi SSH., 1995, "Thermodynamic properties of foods in dehydration". In: Rao MA, Rizvi SSH, editors. Engineering properties offoods, Marcel Dekker, New York, 223-309.

Sadaka, S., and Atungulu, G., 2018, "Grain sorghum drying kinetics under isothermal conditions using thermogravimetric analyzer", BioResources, 13(1), 1534-1547.

Sacilik, K. and Elicin, A. K., 2006, "The thin layer drying characteristics of organic apple slices", Journal of Food Engineering, 73(3), 281-289. https://doi.org/10.1016/j.jfoodeng.2005.03.024

Senadeera, W., Bhandari, B. R., Young, G., \& Wijesinghe, B., 2003, "Influence of shapes of selected vegetable materials on drying kinetics during fluidized bed drying", Journal of Food Engineering, 58(3), 277 283. https://doi.org/10.1016/s0260-8774(02)00386-2 
Sharaf-Eldeen, Y. I., Blaisdell, J. L., and Hamdy, M. Y., 1980, “A model for ear corn drying", Transactions of the ASAE, 23(5), 1261-1271. https://doi.org/10.13031/2013.34757

Srikiatden, J. and Roberts, J. S., 2006, "Measuring moisture diffusivity of potato and carrot (core and cortex) during convective hot air and isothermal drying", Journal of Food Engineering, 74(1), 143-152. https://doi.org/10.1016/j.jfoodeng.2005.02.026

Stintzing, F. C. and Carle, R., 2004, "Functional properties of anthocyanins and betalains in plants, food and in human nutrition", Trends in Food Science and Technology, 15, 19-38. https://doi.org/10.1016/j.tifs.2003.07.004

Togrul, I. T. and Pehlivan, D., 2004, "Modelling of thin layer drying kinetics of some fruits under open-air sun drying process", Journal of Food Engineering, 65(3), 413-425.

https://doi.org/10.1016/j.jfoodeng.2004.02.001

Vedavathi, N., Dharmaiah, G., Balamurugan, K. S., and Ramakrishna, K., 2019, "A study on MHD boundary layer flow rotating frame nanofluid with chemical reaction", Frontiers in Heat and Mass Transfer, 12, 10, 1-9. http://dx.doi.org/10.5098/hmt.12.10

Velic, D., Planinic, M., Tomas, S., and Bilic, M., 2004, "Influence of air flow velocity on kinetics of convection apple drying", Journal of Food Engineering, 64(1), 97-102.

https://doi.org/10.1016/j.jfoodeng.2003.09.016
Verma, L. R., Bucklin, R. A., Endan, J. B., and Wratten, F. T., 1985, "Effects of drying air parameters on rice drying models", Transactions of the ASAE, 28 (1), 296-301. https://doi.org/10.13031/2013.32245

Waheed, M. A., and Komolafe, C. A., 2019, "Temperatures dependent drying kinetics of cocoa beans varieties in the air-ventilated oven", Frontiers in Heat and Mass Transfer (FHMT), 12, 8 http://dx.doi.org/10.5098/hmt.12.8

Wang, Z., Sun, J., Liao, X., Chen, F., Zhao, G., Wu, J., and Hu, X., 2007a, "Mathematical modeling on hot air drying of thin layer apple pomace", Food Research International, 40(1), 39-46. https://doi.org/10.1016/j.jfoodres.2006.07.017

Wang, Z., Sun, J., Chan, F., Liao, X., and Hu, X., 2007b, "Mathematical modelling on thin layer microwave drying of apple pomace with and without hot air pre-drying", Journal of Food Engineering, 80(2), 536544. https://doi.org/10.1016/j.jfoodeng.2006.06.019

Wang, C. Y., and Singh, R. P., 1978, “A single layer drying equation for rough rice", ASAE Paper No. 78-3001, ASAE, St. Joseph, Michigan 49085.

Yaldiz, O., Ertekin, C., and Uzun, H. I., 2001, "Mathematical modeling of thin-layer solar drying of sultana grapes", Energy, 26(5), 457-65. https://doi.org/10.1016/S0360-5442(01)00018-4

Xia, B. and Sun, D. W., 2002, "Application of computational fluid dynamics (CFD) in the food industry: A review", Computer and Electronics in Agriculture, 34(1-3), 5-24. https://doi.org/10.1016/S0168-1699(01)00177-6 